\title{
Effect of The Opopanax Hispidus Plant's Aerial Parts Extract on Mice Ovary
}

\section{Opopanax Hispidus Bitkisinin Gövde Ekstresinin Fare Overi Üzerine Etkileri}

Nese Colcimen ${ }^{1}$ Okan Arihan²,

Safa Gumusok ${ }^{3}$,

Ceyda Sibel Kilic ${ }^{3}$

${ }^{1}$ Van Yuzuncu Y,I University, Faculty of Medicine, Department of Histology and Embryology, Van, Turkey

${ }^{2}$ Hacettepe University, Faculty of Medicine, Department of Physiology, Ankara, Turkey ${ }^{3}$ Ankara University, Faculty of Pharmacy, Department of Pharmaceutical Botany,

Ankara, Turkey

Geliş Tarihi/Received: 29 August 2019

Kabul Tarihi/Accepted: 11 December 2019

Address correspondence to: Nese Colcimen, Van Yüzüncü Yıl University, Faculty of Medicine, Department of Histology and Embryology, Van, Turkey

e-mail: colcimennese@hotmail.com

\section{ORCID}

Nese Colcimen

https://orcid.org/0000-0002-7695-3049

Okan Arihan

https://orcid.org/0000-0001-6201-7383

Safa Gumusok

https://orcid.org/0000-0002-7068-444X Ceyda Sibel Kilic

https://orcid.org/0000-0003-2905-7628

\section{Öz}

Amaç: Opopanax hispidus bitkisi Apiaceae familyasındandır. Tedavi amaçlı yaygın olarak hemoroid kadın infertilitesi ve kanın temizlenmesinde kullanılmaktadır. Çalışmamızda Opopanax hispidus metanolik gövde ekstresini farelere vererek over dokusu üzerinde oluşturduğu histolojik değişiklikleri incelemeyi amaçladık.

Gereçler ve Yöntem: 12 adet erişkin, dişi, Swiss-Albino fare alındı, randomize olarak 2 gruba ayrıldı. Kontrol grubu: Herhangi bir uygulama yapılmadı. Opopanax hispidus grubu: Opopanax hispidus metanolik ekstresi (200 mg/kg/gün) 5 gün oral gavajla uygulandı. Deneyin sonunda, sağ over dokusu eksize edilerek çıkarıldı. Dokular \%10'luk tamponlu formaldehit içinde fikse edildi, rutin histolojik inceleme için takip metodları uygulandı ve akabinde $5 \mu \mathrm{m}$ kalınlığında kesitler alındı. Kesitler hematoksilen-eozin ile boyandı ve ışı mikroskopik incelemeye tabii tutuldu. Stereolojik ölçümde Cavalieri prensibinin modifiye metodu kullanıldı. Total doku volüm oranları, Shtereom 1.5 version paket programında verilmiş noktalı alan cetveliyle ölçüldü. Grupların karşılaştırılmasında Mann-Whitney U testi kullanıldı. Hesaplamalarda, istatistik anlamlılık düzeyi \%5 alındı. Tüm hesaplamalar için SPSS (ver:20) istatistik paket program kullanıldı.

Bulgular: Antral follikül sayısı açısından değerlendirildiğinde istatistiki olarak anlamlı fark bulundu $(p<0.05)$. Gruplar arasında over volümü değerlendirildiğinde Opopanax hispidus grubunda kontrol grubuna göre azalma olduğu ve istatistiki olarak anlamlı olduğu tesbit edildi $(p<0.05)$.

Sonuç: Opopanax hispidus' un over dokusunda olumlu etkiler oluşturarak antral follikül sayısını arttırdığını tesbit ettik ve bu artışın muhtemelen antioksidan etkisinden kaynaklandığını düşünmekteyiz.

\section{Abstract}

Aim: Opopanax hispidus (Friv.) Griseb plant belongs to the Apiaceae family. It is traditionally used for the treatment of hemorrhoids, female infertility, and purification of blood. We aimed to examine the histological changes in the murine ovarian tissue following the administration of a methanolic extract of the aerial parts of the Opopanax hispidus (Friv.) Griseb plant.

Materials and Methods: Twelve adult female Swiss-Albino mice were randomly allocated into 2 groups. Control group received no administration. In the Opopanax hispidus group the methanolic extract (200 $\mathrm{mg} / \mathrm{kg} /$ day) was administered via oral gavage for 5 days. At the end of the experiment right ovarian tissue of each subject was excised. Routine histological processing of tissue samples fixed in $10 \%$ formalin were then sectioned at a thickness of $5 \mu \mathrm{m}$. The sections were stained with hematoxylin and eosin and examined with a light microscope. The modified method of Cavalieri principle was used in the stereological measurement. The total tissue volume ratio was measured with a point counting grid provided by the Shtereom version 1.5 software package. Mann-Whitney $U$ test was used to compare the groups. The significance level was set at $5 \%$. All statistical analyses were performed using SPSS (ver: 20 ) software package.

Results: A significant difference was observed with respect to the number of antral follicles $(p<0.05)$. A comparison of ovarian volumes between the groups revealed a significant decrease in the Opopanax hispidus group $(\mathrm{p}<0.05)$

Conclusion: We demonstrated that Opopanax hispidus exerted positive effects on the ovarian tissue and increased the number of antral follicles, probably due to its antioxidant effect.

Key words: Mice, Opopanax hispidus, ovary, stereology, antioxidant

\section{INTRODUCTION}

Opopanax hispidus plant belongs to Apiaceae family, which is one of the biggest families in the flora of Turkey (1). The plant is known with different names in different regions of Turkey as yellow grass-sari ot, "çörtük", "kaymacık", or "kekire" $(2,3)$. The plant is known to possess antioxidant and antimicrobial activities and its stems and leaves are traditionally used commonly for the treatment of hemorrhoids, female infertility, and purification of blood (4-7). Opopanax hispidus plant contains a high amount of flavonoid and phenolic compounds that protect
Cite this article as: Colcimen N, Arihan O, Gumusok S, Kilic CS. Effect of The Opopanax Hispidus Plant's Aerial Parts Extract on Mice Ovary. Selcuk Med J 2020;36(1): 44-47
Disclosure: None of the authors has a financial interest in any of the products, devices, or drugs mentioned in this article. The research was not sponsored by an outside organization. All authors have agreed to allow full access to the primary data and to allow the journal to review the data if requested. 
against free radical-induced oxidative damage, as well as gram (+), gram (-) and antimicrobial effects against fungi have been found in studies (4-5).

Infertility is a serious health problem, affecting nearly $15 \%$ of couples throughout the world and described as being unable to conceive despite engaging regular sexual intercourse for one year (8). Conventional treatments usually result in a serious physical and economic burden. Due to the traditional usage of the plant, we hypothesized that the plant may contribute to the treatment of infertility. Hence, we planned to administer the methanolic extract of the aerial parts of the plant to mice in an attempt to investigate its histological effects on ovaries by measuring the number of antral follicles and the volume of ovaries.

\section{MATERIALS AND METHODS}

Twelve adult female Swiss-Albino mice weighing between 30-36 g were used in the present study. The mice were housed under a 12-h light/dark cycle at constant temperature and humidity and given access to standard diet and water ad libitum. The study was performed with the approval of the Animal Ethical Committee of Van Yuzuncu Yıl University (No: 2018/06). Mice were randomly allocated to 2 groups each of which containing 6 mice:

1. Control group: No administration was performed.

2. Opopanax hispidus group: Methanolic extract of the aerial parts of Opopanax hispidus (O. hispidus) were administered for 5 days ( $200 \mathrm{mg} / \mathrm{kg} /$ day) via oral gavage. At the end of the experiment, anterior abdominal walls of all groups were opened, and the right ovarian tissues were excised under anesthesia with $75 \mathrm{mg} / \mathrm{kg}$ ketamine hydrochloride (Ketalar, Pfizer, Istanbul, Turkey) injection (i.p).

Plant samples were collected from the below mentioned locality and voucher specimens were kept in Herbarium of Ankara University Faculty of Pharmacy: C3: Akseki, Sadıklar Village entrance, near the fields, $978 \mathrm{~m}, \mathrm{H}$. Duman, C.S. Kılıç, 20/6/2016 (identified by $\mathrm{H}$. Duman). Aerial parts of the plant were grounded, macerated for 8 hours with methanol (Merck, 1060069) for 3 times, and evaporated with a rotary evaporator (Büchi, Germany).

The sampled ovarian tissues were immersed into $10 \%$ buffered formaldehyde for histopathological examination. Following their fixation for 72 hours, they were subjected to routine histological methods and were then embedded in paraffin. Stereology is a measurement technique based on systematic

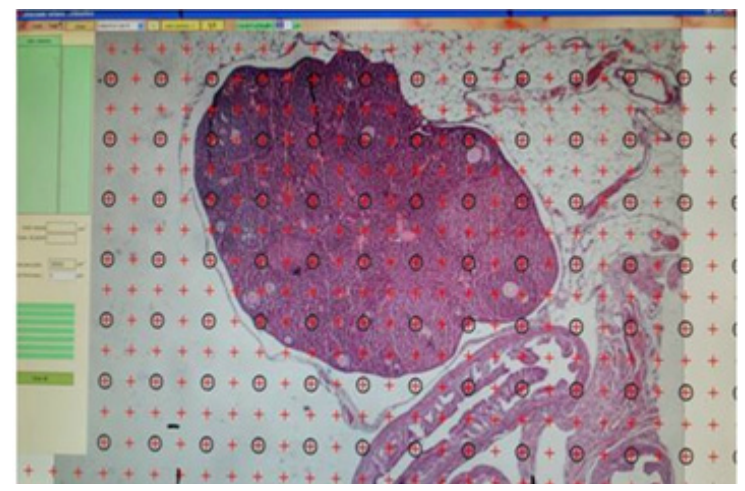

Figure 1. Stereological evaluation of ovary tissue

random sampling, which provides unbiased and precise information. The number of cross-sections and section thresholds to be used in the study were determined by a pilot study. The first cross-section was selected randomly; pairs of consecutive sections having a thickness of $5 \mu \mathrm{m}$ were taken from each block at certain intervals. The cross-sectional range was determined considering that antral follicle size was $200 \mu \mathrm{m}$ (9) and average 10 sections were obtained from each ovarian tissue. Cross-sections were stained with hematoxylin and eosin (H\&E), and then examined in a light microscope (AxioVision 3,1 Zeiss axioplan 2 imaging, Germany, Göttingen) and their photographs taken. Ovarian follicle classification Myers et al. (10) according to the classification used. Counting was performed based on the core structure. Ovarian volume and the number of antral follicles was determined with the modified Cavalieri method known to yield highly accurate results in infertility assessment, with the values of coefficient of variation (CV) and coefficient of error (CE) being within acceptable ranges. $\mathrm{CE}$ and $\mathrm{CV}$ are considered in order to determine the sample size in each group in the stereological studies (11). The total tissue volume ratio was measured with a point grid provided by the Shtereom version 1.5 software package $(12,13)$ (Figure 1).

Mann-Whitney $U$ test was used to compare the study groups. The descriptive values were presented as mean \pm standard deviation. Statistical significance was set at $p<0.05$. SPSS (ver: 20 ) statistical software was used for all statistical analyses.

\section{RESULTS}

A general histological examination revealed a normal ovarian cortical and medullar structure in the control group. In the $\mathrm{O}$. hispidus group, on the 


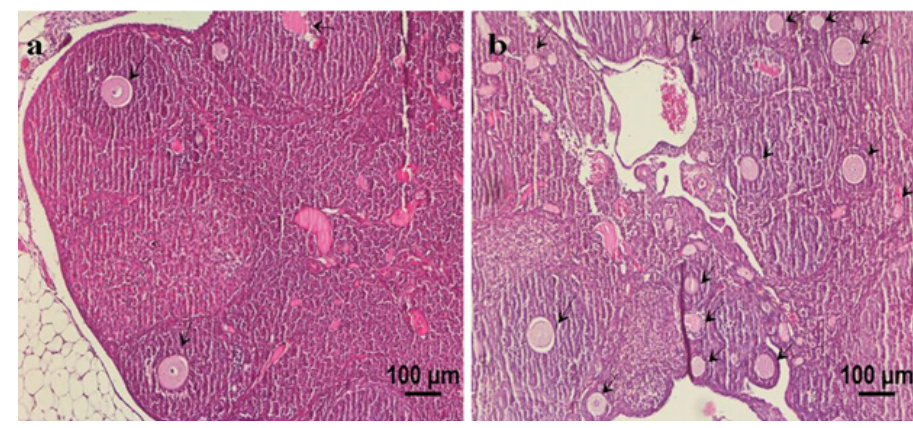

Figure 2. a: Control group b: Opopanax hispidus group, General microscopic image of ovarian tissue, Ovarian follicles (black arrows) (H\&E, Scale bar $100 \mu \mathrm{m})$.

other hand, overall ovarian size was reduced and the cortical ovarian sections contained an excess number of follicles compared to the medulla. As compared with the control group, the $\mathrm{O}$. hispidus group had an increased number of follicles in different stages (Figure 2). We demonstrated that ovarian volume was significantly reduced in the $\mathrm{O}$. hispidus group compared to the control group $(p<0.05)$ (Table 1-Figure 3).

A comparison of the number of antral follicles between the two groups revealed a significantly higher number in the O. hispidus group $(p<0.05)$ (Table 2-Figure 4).

\section{DISCUSSION}

O. hispidus has been traditionally used for the treatment of infertility. However, a review of the literature did not reveal any evidence confirming such biological activity. Assessment of the ovarian reserve is crucial for infertility patients; however, a test that can accurately perform this assessment does not exist yet. Therefore, determination of FSH and estradiol levels on the 3rd day is used as the basic infertility test. As more advanced tests, Clomiphene Citrate Challenge Test (CCCT), Anti Mullerian Hormone (AMH) level, and antral follicle count (AFC) have been introduced (14). In addition to these tests, evaluation of the ovarian volume is used to predict the ovarian reserve. In prior studies, ovarian response is considered to

\section{Total vol.}

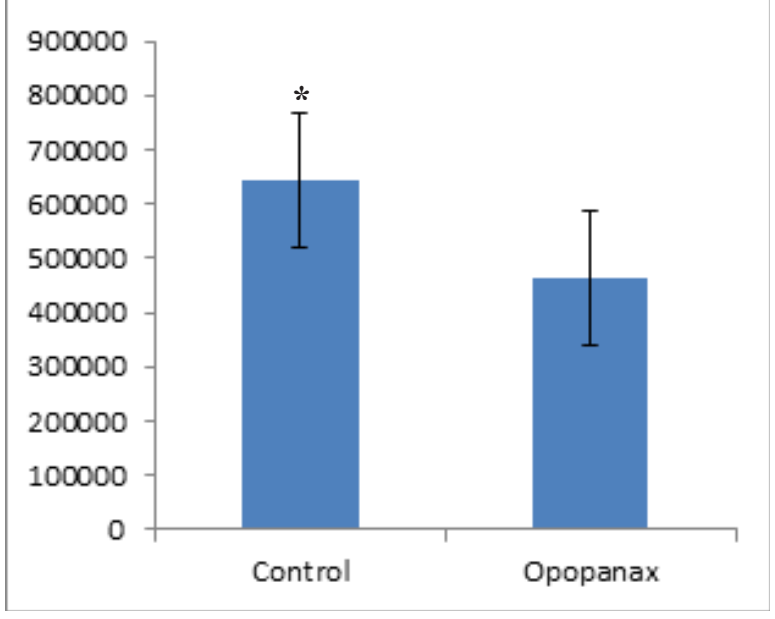

Figure 3. Comparison of total volumes of groups

be poor in patients having an antral follicle number below 6 . Furthermore, antral follicle count has been reported to be a good marker for the determination of outcome of intrauterine insemination (15). Erdem et al. studied 145 patients with idiopathic infertility who underwent 283 cycles; they reported that, among multiple variables such as age, basal $\mathrm{FSH}$, total gonadotropin dosage, HCG day, and dominant follicle count, the antral follicle count was the only variable predicting clinical gestation and live birth (16). Thus, we evaluated the antral follicle count to assess the effects of the plant extract on ovarian reserve. Our results showed that the antral follicle count was significantly higher in the $\mathrm{O}$. hispidus group compared to the control group ( $p<0.05)$. Lass et al. compared two groups of women, with an ovarian volume $<3 \mathrm{ml}$ vs $\geq 3 \mathrm{ml}$. They could not demonstrate any difference in respect to fertilization and gestation (17). When we assessed the ovarian volume, we noted a significant reduction of volume in the $\mathrm{O}$. hispidus group than the control group $(p<0.05)$. However, the number of follicles and the cortex volume were higher than the medulla. This finding suggested that follicle count is a more important parameter than volume predicting

Table 1. Descriptive statistics and comparative results of groups

\begin{tabular}{|c|c|c|c|c|c|c|c|}
\hline \multirow{2}{*}{ Total vol. $\left(\mathrm{mm}^{3}\right)$} & & Mean & Standard Deviation & Minimum & Maximum & Median & $p$ \\
\hline & Control & 644983 & 123727 & 472500 & 787500 & 686275 & \multirow[t]{2}{*}{0,026} \\
\hline & Opopanax & 463650 & 123651 & 328950 & 655200 & 424350 & \\
\hline \multirow[t]{2}{*}{ Antral foll. } & Control & 23 & 6 & 17 & 31 & 23 & \multirow[t]{2}{*}{0,015} \\
\hline & Opopanax & 45 & 14 & 20 & 56 & 50 & \\
\hline
\end{tabular}




\section{Antral foll.}

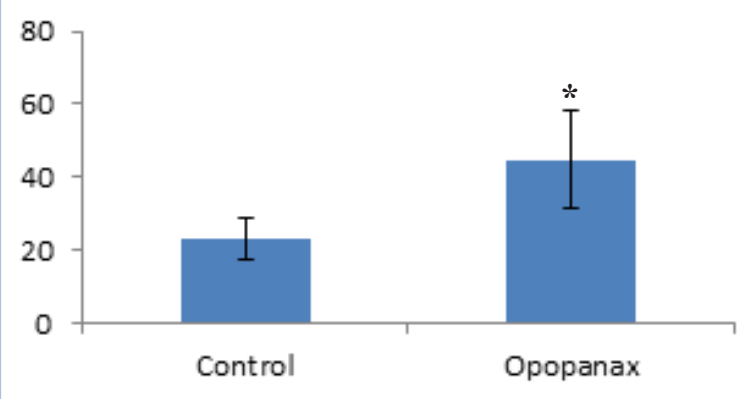

Figure 4. Comparison of number of antral follicles of groups

ovarian reserve. The plant studied herein reportedly possesses antimicrobial activity and contains substantial amounts of phenolic substances and flavonoids, and it also reduces and/or slows down the rate of oxidative stress associated with degenerative disorders (4). Oxidative stress is the imbalance between antioxidant and oxidant processes and the consequent formation of tissue damage; thus, it is known to have an adverse effect on folliculogenesis, to disturb the embryonic development due to its detrimental effects on the membranes, and to cause DNA damage in the sperm and lead to necrospermia, asthenospermia, thus to impair fertilization (18). Herein we demonstrated that the studied plant has a positive effect on ovarian folliculogenesis, which probably occurred by virtue of its antioxidant effect and an increased number of follicles. Infertility treatments generally consist of exhausting and expensive procedures. Our results suggest that this plant species may be a promising treatment option that might positively affect these procedures.

Conflict of interest: Authors declare that there is no conflict of interest between the authors of the article.

Financial conflict of interest: Authors declare that they did not receive any financial support in this study.

Address correspondence to: Nese Colcimen, Van Yüzüncü Yıl University, Faculty of Medicine, Department of Histology and Embryology, Van, Turkey

e-mail:colcimennese@hotmail.com

\section{REFERENCES}

1. Bulut $G$, Tuzlacı E, Doğan A, et al. An ethnoparmacological review on the Turkish Apiaceae species. İstanbul Ecz Fak Derg 2014;44:163-79.
2. Karagözler AA, Aktaş Uygun D, Uygun M. Opopanax hispidus (Friv.) Gris. (Sarı Ot) ve Rosemarinus officinalis L. (Biberiye)'nin antioksidan kapasitelerinin ve prolin düzeylerinin incelenmesi. XX. Ulusal Kimya Kongresi; 4-8 Eylül 2006; Kayseri, Türkiye.

3. Aksakal Ö, Kaya Y. Erzurum ve çevresinde halk tarafından gıdaamaçlı olarak kullanılan bitkiler. Türkiye 10. Gıda Kongresi; 21-23 Mayıs 2008; Erzurum, Türkiye.

4. Matejic J, Dzamic A, Mihajilov-Krstev T, et al. Antioxidant and antimicrobial potential of opopanax hispidus (apiaceae) extracts. Lek Sırov 2015;35:141-50.

5. Gürhan G, Ezer N. Halk arasında hemoroit tedavisinde kullanılan bitkiler-I. Hacettepe Üniversitesi Eczacılık Fakültesi Dergisi 2004;24:37-55.

6. Özgen U, Kaya Y, Houghton P. Folk medicines in the villages of ilıca district (Erzurum, Turkey). Turk J Biol 2012;36:93106.

7. Tan A, Adanacıoğlu N, Karabak S, et al. Biodiversity for food and nutrition: Edible wild plant species of aegean region of Turkey. Anadolu J of AARI 2017;27:1-8.

8. Kızılay F, Altay B. Evaluation of the effects of antioxidant treatment on sperm parameters and pregnancy rates in infertile patients after varicocelectomy: A randomized controlled trial. Int J Impot Res 2019.

9. Koç Mi. Polikistik over sendromu oluşturulmuş fare over dokusunda, GDF-9 ve BMP-15 ekspresyonlarının ve ince yapı değişikliklerinin incelenmesi.Yüksek Lisans Tezi. Mersin Üniversitesi, Sağlık Bilimleri Enstitüsü, Histoloji ve Embriyoloji Anabilim Dalı, Mersin, 2012.

10. Myers M, Britt KL, Wreford NG, et al. Methods for quantifying follicular numbers within the mouse ovary. Reproduction 2004;127:569-80.

11. Gundersen HJ, Jensen EB. The efficiency of systematic sampling in stereology and its prediction. J Microscopy 1987; 1147:229-63.

12. Gundersen HJ, Bendtsen TF, Korbo L, et al. Some new, simple, efficient stereological methods and their use in pathological research and diagnosis. APMIS 1988;96:37994.

13. Howard CV, Reed MG. Unbiased stereology, threedimensionel measurements in microscopy. Oxford: BIOS Scientific Publishers 1998:39-68.

14. Topçu HO, Evliyaoğlu Ö, Şahin Y. Temel infertilite araştırmaları nasıl olmalıdır? Derleme. TJRMS 2017;1:104-11.

15. Şahin G, Tavmergen E. IUl'da başarıyı artırmanın yolları. Derleme. Türkiye Klinikleri J Gynecol Obst-Special Topics 2012;5:21-9.

16. Erdem M, Erdem A, Guler I, et al. Role of antral follicle count in controlled ovarian hyperstimulation and intrauterine insemination cycles in patients with unexplained subfertility. Fertil Steril 2008;90:360-6.

17. Lass A, Skull J, McVeigh E, et al. Measurement of ovarian volume by transvaginal sonography before ovulation induction with human menapausal gonadotrophin for in.vitro fertilization can predict poor response. Hum Reprod 1997;12:294-7.

18. Akdoğan A. Antioksidan ilaçların infertil çiftin geleneksel tedavisine katkısı var mıdır? Derleme. Türkiye Klinikleri J Gynecol Obst-Special Topics 2012;5:1-5. 